*Mestre em Direito pela Universidade do Estado do Rio de Janeiro (UERJ). Membro da Rede de Pesquisa Interinstitucional em Direito da Cidade da Universidade do Estado do Rio de Janeiro (RPIDC/UERJ) e do Laboratório de Estudos de Direito Administrativo Comparado da Universidade Federal do Estado do Rio de Janeiro (LEDAC/UNIRIO). Membro da Comissão de Direito Administrativo e de Direito Constitucional do Instituto dos Advogados Brasileiros (IAB). Membro do Instituto de Direito Administrativo do Estado do Rio de Janeiro (IDARJ). Advogado. E-mail: ericsantos13@gmail.com

**Professor Convidado do Mestrado e Doutorado em Direito da Universidade do Estado do Rio de Janeiro (UERJ). Professor Permanente do Mestrado em Direito da Universidade Federal do Estado do Rio de Janeiro (UNIRIO) Professor da Pós-Graduação em Direito Administrativo da Pontifícia Universidade Católica (PUC-RJ), Universidade do Estado do Rio de Janeiro (UERJ) e da Escola de Magistratura do Rio de Janeiro (EMERJ). Professor Adjunto da Universidade Federal do Estado do Rio de Janeiro (UNIRIO) e da Universidade Federal Rural do Rio de Janeiro (UFRRJ). Doutor em Direito pela Universidade do Estado do Rio de Janeiro (UERJ). Mestre em Direito Constitucional e Especialista em Direito Administrativo da Universidade Federal Fluminense (UFF).Vice-presidente da Comissão de Direito Administrativo do Instituto dos Advogados Brasileiros (IAB).Idealizador, Fundador, e Diretor Acadêmico do Instituto de Direito Administrativo do Rio de Janeiro (IDARJ).

E-mail: emersonacmoura@yahoo. com.br

\section{Cabo Frio e as potencialidades da Região Lagos: DO PLANO DE DESENVOLVIMENTO INTEGRADO PARA O TRANSPORTE PÚBLICO COLETIVO INTERMUNICIPAL}

THE MUNICIPALITY OF CABO FRIO AND THE POTENTIALITIES

OF THE REGIÃO DOS LAGOS: FROM THE INTEGRATED

DEVELOPMENT PLAN TO INTERMUNICIPAL COLLECTIVE PUBLIC TRANSPORT

\section{Eric Santos Andrade* Emerson Affonso da Costa Moura**}

Como citar: ANDRADE, Eric Santos; MOURA, EmersonAffonso da Costa. Cabo Frio e as potencialidades da Região Lagos: do plano de desenvolvimento integrado para o transporte público coletivo intermunicipal. Revista do Direito Público, Londrina, v. 16, n. 3 , p. 168-191, dez. 2021. DOI: 10.5433/24157-108104-1.2021v16n 3p.168. ISSN: $1980-511 \mathrm{X}$

Resumo: O presente estudo tem como proposta a rediscussão do desenvolvimento político e urbano da microrregião dos Lagos do Estado do Rio de Janeiro, qualificado como um aglomerado urbano. Essa classificação tem suma importância no que tange à discussão da melhoria dos transportes públicos intermunicipais, no que diz respeito às necessidades inerentes e as peculiares da região industrial, assim como da prestação de múltiplos serviços locais. Assim, levanta-se a questão do desenvolvimento urbanístico do município de Cabo Frio e, ao final, faz-se uma correlação com a necessidade de um plano integrado frente ao último estudo desenvolvido pelo IBGE, que qualifica os municípios ao derredor de Cabo Frio como um crescente centro de cultura política de interesse comum.

Palavras-chave: Plano de desenvolvimento integrado; Transporte intermunicipal; Regiões metropolitanas; Administração pública municipal.

Abstract: The present study proposes to rediscuss the political and urban development of the micro região dos lagos (lake region) in the State of Rio de Janeiro, qualified as an urban agglomeration. This classification is extremely important when it comes to the discussion of improving inter-municipal public transport, with regard to the inherent and peculiar needs of the industrial region, as well as the provision of multiple local services. Thus, the issue of urban development in the municipality of Cabo Frio is raised and, at the end, there is a correlation with the need for an integrated plan in view of the last study developed by IBGE, which qualifies 
the municipalities around Cabo Frio as a growing center of political culture of common interest.

Keywords: Integrated development plan; Intermunicipal transport;

Metropolitan regions; municipal public administration. 


\section{INTRODUÇÃO}

Com a Constituição de 1988 a remodelagem do desenho federativo brasileiro traz novos sentidos à repartição de competências institucionais. Nele, ascende os entes municipais, reconhecidos como entes federativos e dotados de autonomia político-administrativo. Esse novo desenho institucional tem a visão de que em cima da proposta de desconcentração da figura do Estado unitário, visto que segundo Diogo de Figueiredo Moreira Neto (2014, p. 87) o Estado é uno e indivisível, mas que está separado em poderes, composto por entes autônomos com o objetivo final de conseguir dar efetividade à gestão de pessoas, bens e serviços, conforme sejam os interesses que os definem: se federal, regional ou local. Dessa maneira, os municípios possuem importante papel de destaque frente à administração dos interesses locais, consoante está prevista na Constituição Federal.

Todavia, a realidade administrativa avança cada vez mais, emergindo novas questões que tem demandado ações cooperativas entre os entes federados. Percebeu-se que devido a globalização intensa e o avanço tecnológico as cidades tem se aproximado e compartilhado mais e mais de suas vivencias locais, ao ponto de surgirem questões que extrapolam os limites dos interesses locais apenas de um único município.

A ideia de regionalização vem não no sentido de contrariar ou enfraquecer a divisão institucional da Administração Direta, no que diz respeito à gestão de bens, serviços e de pessoas em obediências à lei e conforme a prossecução do interesse público, mas sim fortalece a compreensão de que a autonomia constitucionalmente reconhecida aos entes está envolto precipuamente da necessidade de cooperação institucional, o que irá justificar, em outras palavras, um plano de desenvolvimento integrado.

Nesse contexto, é promulgada a Lei $\mathrm{n}^{\circ} 13.089$, de 12 de janeiro de 2015, que institui o Estatuto da Metrópole e cuida de delimitar conceitos sobre o que se entenderá sobre região metropolitana, função compartilhada de serviços de comum interesse, governança interfederativa, plano de desenvolvimento urbano integrado etc.

Acontece que mesmo se tratando de contextos urbanos-administrativos que envolvem interesses de uma determinada região, composto por vários municípios que não necessariamente representam todo o Estado, tem-se apercebido por meio de estudo do IBGE que as potencialidades de desenvolvimento integrado de certos locais do país não são devidamente explorados, afinal, o seu reconhecimento e sua disciplina parte em um primeiro momento da sua criação legal pelo Estado federativos, conforme competência reconhecida pela Constituição no seu art. $15, \S 3^{\circ}$.

A proposta do presente trabalho é de delimitar como que é reconhecida essa potencialidade interfederativa a partir do estudo da Micro Região dos Lagos no Rio de Janeiro, tendo como centro o município de Cabo Frio. Pergunta-se em que medida a aplicação da gestão interfederativa, valendo-se do plano de desenvolvimento integrado naquela região contribui para um crescimento regional, ao ponto de suprir também a necessidades de municípios menores e distritos que estão crescendo e dependem economicamente de políticas públicas dos municípios maiores. Se 
propõe também esclarecer como que a ideia de cooperação interfederativa por meio da disciplina legislativa consegue fazer força para evitar que haja desproporções na interferência dos demais entes federados que, por vezes, acabam administrando questões de interesse regional que não deveria lhes ser devido, dado a peculiaridade da potencialidade de gestão interfederativa local.

Para tanto, o objeto da presente pesquisa se limitará sobre a principal potencialidade que envolve toda a Região dos Lagos - o transporte público coletivo intermunicipal. Será discriminado todas as suas peculiaridades e dificuldades, a fim de trazer ao leitor esclarecimento sobre como que vem acontecendo a gestão do transporte público coletivo intermunicipal naquela região e como que essa forma, desprovida da ideia de gestão interfederativa, acaba estagnando toda a desenvoltura potencial de uma verdadeira microrregião. Ainda, será discutido em que medida a legislação tem os instrumentos necessários para munir os entes federados de meios capazes de explorar ao máximo suas funções públicas e serviços de interesse comum (FPICs).

Dessa maneira, será utilizado preferencialmente de estudo comparativo bibliográfico com a análise legislativa vigente. Parte-se da hipótese que a Região dos Lagos atualmente possui um dos maiores índices potenciais de gestão interfederativa do país, ao ponto de que a tomada de decisões políticas municipais interfere, embora indiretamente, na gestão político-administrativa dos demais entes. Não ao ponto de haver usurpação de competência e violação do pacto federativo horizontal, mas sim na proporção de que as funções públicas e serviços daqueles entes que estão quase que na sua totalidade interligados, sejam por questões culturais, geográficas e históricas, como se verá a adiante.

\section{CABO FRIO: UM VERDADEIRO AGLOMERADO URBANO FLUMINENSE}

Rediscute-se as potencialidades socioespaciais e políticas dos municípios que compõe a microrregião fluminense, institucionalizada pelo Estado do Rio de Janeiro. A Lei Complementar $\mathrm{n}^{\circ}$ 87, de 16 de dezembro de 1997, dispõe sobre a região metropolitana do Rio de Janeiro, sua composição, organização e gestão, bem como sobre o que se entenderá por microrregião dos lagos, definindo as funções públicas e serviços de interesse comum (FPICs).

A Lei Complementar terá sua redação posteriormente alterada pela lei complementar $\mathrm{n}^{\circ}$ 133, de 15 de dezembro de 2019, que delimita com maior precisão os municípios componentes da Região dos Lagos. A microrregião é formada pelos municípios de Cabo Frio, Araruama, Armação de Búzios, Arraial do Cabo, Iguaba Grande, São Pedro da Aldeia, Saquarema e Silva Jardim. Todos estes entes municipais foram postos juntos tendo em vista a possibilidade de planejamento e execução das FPICs, segundo a legislação ${ }^{1}$.

O desenvolvimento socioespacial e econômico da microrregião lagos era fato evidente, muito antes da sua institucionalização em 1997. Porém, somente a partir da Constituição Federal

1 Para mais informações ver: art. $2^{\circ}$ da Lei Complementar $n^{\circ} 133$, de 15 de dezembro de 2009, que dispõe sobre a instituição da Região Metropolitana do Rio de Janeiro e da Microrregião dos Lagos. Disponível em: https://govrj.jusbrasil.com.br/legislacao/820932/lei-complementar-133-09. Acesso em: 17 fev.2020. (RIO DE JANEIRO, 2009a). 
de 1988 que, pela primeira vez, o Estado do Rio de Janeiro utilizou-se da sua nova competência constitucional para instituir formalmente a microrregião dos Lagos². Por meio da Lei Complementar $\mathrm{n}^{\circ}$ 87/97, posteriormente modificada pela LC $\mathrm{n}^{\circ} 105 / 02$, criou-se o Conselho Deliberativo da microrregião dos Lagos (CDML). Trata-se de órgão formado por 16 membros que são submetidos primeiramente à Assembleia Legislativa do Estado do Rio de Janeiro (ALERJ) e nomeados pelo Governador, com mandato de 02 (dois) anos ${ }^{3}$.

No que tange à Microrregião dos Lagos fica em maior evidência a cidade de Cabo Frio que desenvolveu-se de forma progressiva desde 1990, ao ponto de ser levada em consideração como um centro de aglomeração urbana. É um período onde os royalties do petróleo estão em alta no mercado internacional. Desta última vez, o Instituto Brasileiro de Geografia e Estatística (2015, p. 68) tem atentado ao processo de urbanização brasileiro, que tem cada vez mais tomado grandes proporções, e chegou a classificar o município de Cabo Frio como uma das novas aglomerações urbanas, embora não metropolitana, que devem ser melhor acompanhada de perto.

Segundo a pesquisa técnica, Cabo Frio tem reflexos de novos processos de divisão técnica e territorial de trabalho. Seu maior efeito acaba sendo a atração de relações mais complexas entre os municípios vizinhos, sejam eles contínuos ou não. $\mathrm{O}$ que chama atenção é o fato de possuir característica de nítido processo de metropolização, o que é possível no atual contexto do Rio de Janeiro onde não mais necessariamente ter-se-á uma região metropolitana com uma única metrópole figurando como possível polo no contexto estadual (TERRA; SOUZA, 2017, p. 818).

O Estatuto da Metrópole possui os critérios intrínsecos e extrínsecos para a formalização de novas Regiões Metropolitanas (RM) no país. Dentre os requisitos, as RM deverão apresentar relevantes demandas socioeconômicas e políticas, bem como possua influência nacional ou regional figurando, no mínimo, como área de influência, segundo os dados a serem definidos pelo Instituto Brasileiro de Geografia e Estatística (2015, p. 69)4.

A proposta é de apresentar a Microrregião dos Lagos como potência socioeconômica e política, que está pretendendo preencher aos requisitos da institucionalização de uma nova RM do Rio de Janeiro. Portanto, se faz importante fazer uma análise do seu contexto juspolítico e econômico a partir dos estudos recentes do IBGE intitulado de Arranjos Populacionais e Concentrações Urbanas do Brasil. Este estudo técnico tem alvo na identificação de novas aglomerações urbanas em potencial no país ${ }^{5}$. Antes de adentrar-se especificamente nas considerações técnicas ou limitações

2 Para mais informações ver: art. $25, \S 3^{\circ}$ da Constituição Federal de 1988, que dispõe sobre a Constituição da República Federativa do Brasil. Disponível em: http://planalto.gov.br/ccivil_03/constituicao/constituicao.htm. Acesso em: 17 fev. 2020. (BRASIL, 1988).

3 Para mais informações ver: art. $3^{\circ}$ da Lei Complementar $n^{\circ} 105$, de 04 de julho de 2002, que dispõe sobre alteração da lei complementar no 87, de 17 de dezembro de 1997. Disponível em: https://gov-rj.jusbrasil. com.br/ legislacao/87467/lei-complementar-105-02. Acesso em: 19 fev. 2020. (RIO DE JANEIRO, 2002).

4 Para mais informações ver: art. $2^{\circ}$, inciso $\mathrm{V}$ da Lei $\mathrm{n}^{\circ} 13.089$, de 12 de janeiro de 2015 , que institui o Estatuto da Metrópole, altera a Lei $\mathrm{n}^{\circ} 10.257$, de 10 de julho de 2001 e dá outras providências. Disponível em:

http://www.planalto.gov.br/ccivil_03/_ato2015-2018/2015/lei/113089.htm. Acesso em: 28 fev.2020. (BRASIL, 2015).

5 Segundo a pesquisa os arranjos populacionais, os de localização litorânea voltada para atividades turísticas e de veraneio constituem um modelo de urbanização próprio. Comumente, nota-se que as áreas urbanizadas são contíguas ou muito próximas umas das outras e que acompanham a orla marítima. Essa característica é reforçada quando se observam os dados, pois, dos 49 municípios envolvidos, apenas cinco não possuem contiguidade (3 km ou menos) de suas manchas urbanizadas principais em relação aos demais municípios. Tal característica, porém, nem sempre é acompanhada por movimentos pendulares intensos para trabalho e estudo. São arranjos que expandiram seus 
desta será rediscutido o desenvolvimento do município de Cabo Frio e seus entornos.

CF se mostrou como um dos municípios de grande relevância nacional, no que tange ao desenvolvimento regional. Os repasses de royalties de petróleo agregados ao orçamento municipal o colocam em posição de destaque entre as cidades consideradas de médio porte. A Agência Nacional de Petróleo (ANP) considerou Municípios ricos na Microrregião dos Lagos no ano de 2014 aqueles que recebem monta não inferior a R\$ 45 milhões de reais, dentre os quais Cabo Frio despontou com valor real final de $\mathrm{R} \$ 208,6$ milhões.

Tabela 1 - Royalties em reais (corrigido pelo IGP-DI)

\begin{tabular}{ccll} 
MUNICÍPIO/ESTADO & ANO & \multicolumn{1}{c}{ VALOR CORRENTE } & \multicolumn{1}{c}{ VALOR REAL } \\
CABO FRIO/RJ & 2014 & $\mathrm{R} \$ 197.868 .413,00$ & $\mathrm{R} \$ 208.604 .428,73$ \\
ARMAÇÃO DE BÚZIOS/ RJ & 2014 & $\mathrm{R} \$ 72.488 .760,97$ & $\mathrm{R} \$ 76.416 .833,93$ \\
ARARUAMA/ RJ & 2014 & $\mathrm{R} \$ 10.872 .449,73$ & $\mathrm{R} \$ 11.458 .352,90$ \\
IGUABA GRANDE/ RJ & 2014 & $\mathrm{R} \$ 7.438 .701,85$ & $\mathrm{R} \$ 7.839 .569,98$ \\
SÃO PEDRO DA ALDEIA/ RJ & 2014 & $\mathrm{R} \$ 10.300 .006,78$ & $\mathrm{R} \$ 10.855 .065,03$ \\
SAQUAREMA/ RJ & 2014 & $\mathrm{R} \$ 15.815 .871,44$ & $\mathrm{R} \$ 16.602 .454,85$ \\
ARRAIAL DO CABO/ RJ & 2014 & $\mathrm{R} \$ 45.041 .384,09$ & $\mathrm{R} \$ 47.487 .896,22$
\end{tabular}

Fonte: Distribuição Royalties (AGÊNCIA NACIONAL DE PETRÓLIO, 2020).

No ano de 2018 o total percebido pelo município de Cabo Frio não foi tão diferente da capital, sendo R \$ 152,7 milhões contra 175,1 milhões. Portanto, partir-se do pressuposto que CF pode ser considerado o município com mais recursos da Microrregião dos Lagos e que chama atenção por se encontrar geograficamente no epicentro do desenvolvimento da região. A sua categorização de polo regional começa no final da década de 1990.

A crítica ao estudo técnico do IBGE está na ausência da fundamentação teórica e histórica do município, necessários na compreensão do seu real enquadramento como aglomeração urbana. Pelo instituto a reclassificação de CF leva em consideração apenas dois aspectos: 1) densidade demográfica e 2) proximidade física dos centros populacionais (PINHEIRO, 2016, p. 17-18). Sem essa devida análise, não se vislumbra a amplitude das FPICs daquela região, muito menos as demandas dos municípios as redondezas, que clamam por novas estratégias de arranjos regionais cada vez mais eficientes e modernos.

Não se tem um conceito delimitado de aglomeração urbana, sendo verdadeiro ponto comum trabalhado por diversos ramos do conhecimento: como a geografia, a demografia etc. Com o Estatuto da Cidade, no âmbito jurídico, o termo ganha delimitações legais, sendo a unidade territorial urbana constituída pelo agrupamento de dois ou mais municípios limítrofes, que possuem uma complementariedade funcional entre si (ambiental, geográfica, política e socioeconômica) ${ }^{6}$. Dessa maneira, a compreensão de aglomeração urbana está além da ideia trazida pelo IBGE que

tecidos urbanos para atender à demanda de veraneio de grandes metrópoles próximas. Cabo Frio/RJ juntamente com Araruama/RJ formam o segundo maior conjunto, com 464236 pessoas, seguido do Arranjo Populacional de "Caraguatatuba - Ubatuba - São Sebastião/SP", com 281779 pessoas.

6 art. $2^{\circ}$, inciso I da Lei ${ }^{\circ} 13.089$, de 12 de janeiro de 2015, que institui o Estatuto da Metrópole, altera a Lei ${ }^{\circ}$ 10.257, de 10 de julho de 2001, e dá outras providências. Disponível em: http://www.planalto.gov.br/ccivil_03/_ ato2015-2018/2015/lei/113089.htm. Acesso em: 28 fev. 2020. (BRASIL, 2015). 
prima por aspectos puramente geográficos de densidade populacional, isto é, técnicos.

O município de CF, o sétimo mais antigo do Brasil, teve desde seus primórdios de colonização a produção voltada para o sal, algumas variedades de passeios turísticos e, a partir da década de 80, é que o contexto produtivo sofre mudanças significativas. Nesse mesmo ínterim, CF tem sua densidade demográfica progressivamente aumentada, chegando a sofrer o processo de periurbanização (TERRA; SOUZA, 2017, p. 812-813). Este fenômeno trouxe novos olhares sobre a cidade, não se limitando mais a um centro urbano, mas surge uma complexização das relações urbanísticas ao seu derredor e incorre nos fluxos intra e interurbanos com os municípios vizinhos em uma teia de interdependência política e econômica (PINHEIRO, 2016, p. 50).

Fala-se de um processo histórico que favorecem o reconhecimento de forma mais assídua da Microrregião dos Lagos, principalmente considerando os arredores de CF, como verdadeira aglomeração urbana. O município de CF não mais consegue se ater no planejamento urbano apenas de suas estruturas internas, mas acompanha um verdadeiro planejamento regional (intraurbana e interurbana).

CF se tornou o polo regional da Lagos devido as suas características socioeconômicas e seu posicionamento geográfico. O município faz limites com os municípios de Arraial do Cabo, Armação de Búzios, São Pedro da Aldeia, e o distrito de Tamoios. O município sempre se mostrou bastante atrativo perante os olhos da Coroa Portuguesa e dos demais estrangeiros, pois ofertava uma localização estratégica para a navegação, abrigo de embarcações contra ventanias e marés, e facilidade de extração de pau-brasil nas matas (PINHEIRO, 2016, p. 57).

O primeiro planejamento urbano do município vem com os projetos do engenheiro Major Bellegard a partir de 1822. O projeto estava voltado para construção do farol na ilha de CF e a regularização das ruas principais. A economia do município estava na agricultura, fomentada pela cultura da escravatura. Após a sua abolição restou apenas a exploração comercial do sal e a sua industrialização. Procurando outras atividades lucrativas o município começou a desenvolver os polos de turismo e na implantação da estrada de ferro (PINHEIRO, 2016, p. 60).

Surge então no século XIX a primeira política de mobilidade com a construção da nova ferrovia Niterói-Cabo Frio. Concomitantemente, foi inaugurada a Rodovia Amaral Peixoto, com objetivo de facilitar o escoamento dos produtos de sal com destino principalmente ao município do Rio de Janeiro (MONIÉ, 2003, p. 55). No ano de 1943, o Governo do Rio de Janeiro elaborou o primeiro plano de urbanização das cidades fluminenses, apresentado no escritório Coimbra Bueno. 
Foto 1 - Plano de urbanização de Cabo Frio e de zoneamento ${ }^{7}$

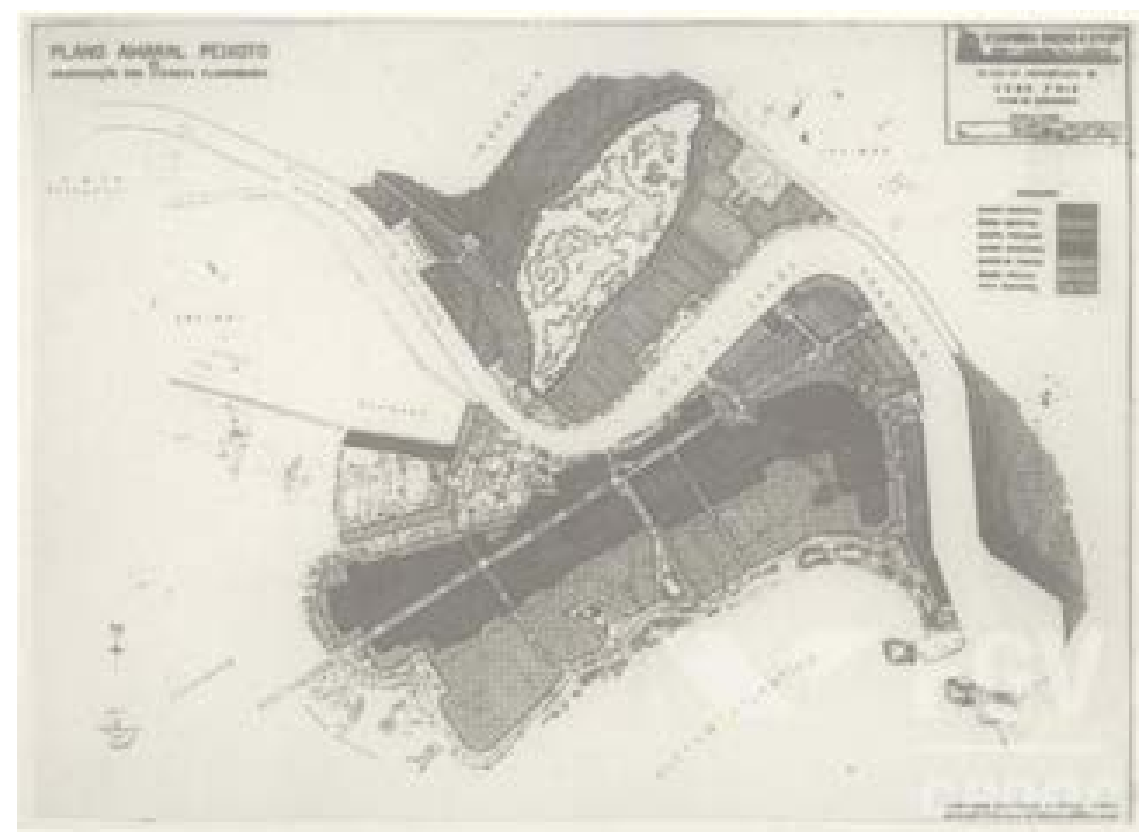

Fonte: (Fundação Getúlio Vargas, 2009).

Tratava-se de plano onde, pelos técnicos da época, já se levava em consideração os municípios limítrofes e suas potencialidades econômicas e turísticas. Neste mesmo, ano o Governo de Getúlio Vargas, foi criada a Companhia Nacional de Álcalis, localizada no município vizinho Arraial do Cabo, que naquele período fazia parte do distrito de CF. Tamanha empreitada à nível nacional trouxe uma explosão no desenvolvimento urbano e social para aquela região. Em 1960, CF ganha duas novas grandes usinas de beneficiamento de sal que já abasteciam todo o país (PINHEIRO, 2016, p. 63).

O turismo foi fator preponderante também na expansão territorial e econômica do município. Conhecida internacionalmente por suas belezas naturais e praias cristalinas, a circulação de pessoas explodiu consideravelmente com a inauguração da Ponte Rio-Niterói, no ano de 1974. Assim, a nova condição de circulação trouxe uma demanda comum para o município de CF e arredores - mobilidade urbana (PINHEIRO, 2016, p. 66).

A participação dos municípios na repartição dos royalties de petróleo, segundo o IBGE, trouxe para os municípios da região litorânea do Rio de Janeiro um movimento migratório intenso, em razão da busca por trabalho.

A descentralização-administrativa que vingou a partir da Constituição Federal de 1988 destacou um novo modelo gerencial da coisa pública no país. Tanto os Estado quanto os Municípios ganharam maior autonomia para a formalização de regiões de desenvolvimento conjuntivo Regiões Metropolitanas, aglomerados urbanos e Microrregiões (CORDEIRO, 2016, p. 87).

O objetivo é trazer para o nível federativo uma nova política legislativa que efetivasse melhorias no que tange à gestão de políticas urbanas de comum interesse, dada uma regionalidade com características socioeconômicas e política própria reconhecidas. Nesse âmago, a competência

\footnotetext{
7 Disponível no acervo público da Fundação Getúlio Vargas (2009).
} 
para formalização passou a ser dos Estados. A nível estadual, a Constituição do Estado do Rio de Janeiro de 1989 (CE-RJ) prevê que a criação se dará por meio de lei complementar. Deve ser observado que a formalização visa precipuamente assegurar a concretização de políticas públicas urbanas de interesse comum da região ${ }^{8}$.

A LC n ${ }^{\circ}$ 87/97, que além de institucionalizar a RM do Rio de Janeiro e da Microrregião dos Lagos (aqui contemplado CF), trouxe uma estrutura legal e uma gestão interfederativa que nunca foram efetivadas. A legislação não delimitava com certeza técnica o que seria considerado Região Metropolitana ou aglomerado urbano ou Microrregião. Dessa maneira, tecer-se-á no próximo tópico como se deu as bases da gestão interfederativa (horizontal e vertical) na região Lagos e suas dificuldades.

\section{DA POSSIBILIDADE DE GESTÃO INTERFEDERATIVA NA REGIÃO DOS LAGOS}

Tema que tem trazido bastante discussão, no quesito cooperação interfederativa, tem sido a gestão dos interesses comuns de uma determinada região, onde há interesses e demandas socioeconômica comuns. Em nome do progresso e da modernidade, a proposta do novo regime interfederativo com a Constituição Federal não foi apenas de descentralizar as influências políticas dos entes, mas de atribuir aos entes, nos seus mais diversos níveis federativos, uma maior autonomia e liberdade em suas escolhas políticas.

Glauber Cordeiro, no seu estudo acerca das Regiões Metropolitanas e o papel dos parlamentos metropolitanos na governança interfederativa, traz uma noção diferenciada sobre a visão do papel desempenhado por cada ente federativo. Para o autor, não é digno sustentar que cada ente está equilibrado, seja no sistema vertical ou seja no horizontal. A União acabou detendo para si a maior parte dos instrumentos capazes de gerar receitas, enquanto que aos municípios foi deixada a mais árdua das tarefas: cuidar do interesse local e ainda contar com recursos para atender as demandas internas. Se já não bastasse haver esta tarefa complexa, a possibilidade de constituir uma Região Metropolitana ou um Aglomerado urbano pode se apresentar como um ponto positivo ou negativo (CORDEIRO, 2016, p. 38-40).

Positivo porque a cooperação na gestão de FPICs contribui para aqueles municípios menores conseguirem se desenvolver e comporem uma malha urbana contínua progressista. Contudo, pode ser extremamente negativo sob a ótica que os municípios com maior influência acabam vindo a exercer uma gestão monopolizada, voltando os interesses da gestão interfederativa para os seus próprios particulares.

Diante dessa nova perspectiva que recai sobre a Microrregião dos Lagos há um entendimento maior a qual nós aqui nos filiamos que é a da consolidação de uma gestão empresarial do ente municipal. Explica-se melhor: os gestores municipais necessitam encontrar soluções alternativas para contornar estes obstáculos econômico-financeiros. O primeiro, se mantém inerte 8 RIO DE JANEIRO. Art. 75 da Constituição do Estado do Rio de Janeiro (1989). Disponível em: https://www2.senado.leg.br/bdsf/handle/id/70450. Acesso em: 4 mar. 2020. (RIO DE JANEIRO, 1989). 
e permanecem na perspectiva arriscada de contar com os recursos extras junto aos entes estaduais e à União para atenderem as demandas populares. A segunda alternativa seria os gestores assumirem uma posição proativa frente a busca de alternativas de gerar receitas e conseguir desenvolver novos contextos administrativos que tragam uma dinamização e maior eficiência na prestação das políticas públicas municipais 9 .

É considerado que a gestão interfederativa vem com essa proposta de tornar os coparticipantes das Regiões Metropolitanas verdadeiros empreendedores, sem que percam seu caráter público (CORDEIRO, 2016, p. 112). A necessidade populacional força cada vez mais os gestores a buscar investir nas suas potencialidades. A Microrregião dos Lagos tem cada vez mais demandado políticas de mobilidade urbana, isso em razão da prática do turismo, transporte de cargas de diversos produtos (petroquímicos, salinos, etc.) além de contemplar uma massa de trabalhadores que trabalham nas indústrias ou que residem na região e laboram em outros municípios vizinhos. A demanda pelo transporte rodoviário superou o ferroviário ao ponto de que é de interesse comum de toda microrregião a oferta regular e eficiente do transporte rodoviário intermunicipal.

A possibilidade de formalizar essa interação entre os entes, de fato, já existia antes mesmo da Constituição Federal de 1988. Contudo, pode ser considerada o marco histórico da era da gestão pública empreendedora como meio de consecução dos interesses públicos locais. A tendência é de cada vez mais o gestor, principalmente o municipal, criar estratégias empreendedoras para atrair o empresário e formar as parcerias ou captar atenção dos demais entes públicos e criar um sistema de cooperação, como, por exemplo, os consórcios públicos e as regiões metropolitanas (CORDEIRO, 2016, p. 44-46) ${ }^{10}$.

Apesar de haver uma legislação genérica e abstrata, não há no Estado do Rio de Janeiro nenhuma aglomeração urbana formalmente reconhecida. Acredita-se que ainda persistem muitas dúvidas técnicas acerca da conceituação de termos próprios entre RM, aglomerações urbanas e Microrregiões, principalmente na visão do corpo legislativo estadual (CORDEIRO, 2016, p. 3940). O que para o presente estudo não chega a ser relevante, pois uma vez que a região, juntada pelas demandas de interesse comum, consigam atender as suas perspectivas, o conceito certo de cada termo está em segundo plano. Tanto o planejamento regional quanto a gestão, nestes casos, almejam atender aos interesses públicos intermunicipais. Este fato tem sido cada vez mais relevante para a desenvoltura de novos processos de urbanização dos municípios da Microrregião Lagos (PINHEIRO, 2016, p. 102).

A pesquisa do IBGE sobre o município de CF possuir a potencialidade de um Aglomerado Urbano não é de todo errado, pois como visto, possui não apenas similitudes demográficas, mas também é preciso levar em consideração as peculiaridades históricas, urbanísticas e econômicas da

\footnotetext{
9 A conjuntura da pretensão do constituinte (art. $25, \S 3^{\circ}$ da CFRB/88) com a do legislador (Estatuto da Metrópole) é nitidamente de trazer uma nova concepção jurídica acerca da gestão interfederativa sob os moldes do modelo neoliberal. A ideia é de atribuir a gestão um viés essencialmente de efetividade administrativa, tudo isso por meio do planejamento, estabelecimento de metas e resultados. Essa estruturação visa ao final a concretização do interesse público, em especial, do interesse público local. É denominado de gestão pública gerencial.

10 Não há sombras de dúvidas que cada vez mais o processo administrativo municipal contemporâneo tem obrigado os gestores a desburocratizarem suas ações próprias, sob pena de caírem na ineficiência das políticas sociais.
} 
região. Eventual caraterização de aglomeração urbana na Região dos Lagos depende, portanto, mais de uma institucionalização formal do que factual (INSTITUTO BRASILEIRO DE GEOGRAFIA E ESTATÍSTICA, 2010).

Aglomeração ou concentração urbana é formada por municípios ou arranjos populacionais que tem uma margem superior a 100 mil habitantes, sendo que será considerado de médio porte quando detiver uma população acima de 100 até 750 mil habitantes. Os municípios de grande porte são aqueles que contam com uma população superior a 750 mil habitantes. Note que os critérios do IBGE são nitidamente técnicos e consideração relevante apenas a densidade demográfica ${ }^{11}$. Discorda-se de forma parcial desse entendimento, como visto anteriormente, a consolidação de uma região para fins de desenvolvimento de interesses comuns leva tem outros pressupostos também indispensáveis, como o contexto econômico, social e político.

Dessa maneira, um reconhecimento de CF e municípios arredores como aglomerado urbano chama atenção para a institucionalização de um planejamento regional mais adequado. Como já explicitado, a lei complementar $n^{\circ} 87$ não traz até hoje resultados significativos para a Região dos Lagos, limitando a expectativa de uma gestão cooperativa eficaz que está limitada apenas no papel.

Um grande benefício à região seria a potencializar seus interesses com arranjos institucionais consorciados, isso envolvendo a sociedade civil, institucionalização de órgãos deliberativos e consultivos a nível regional, maior troca de experiências entre as câmaras municipais que trariam discussões acerca de demandas públicas de interesses comuns. Isso demonstraria aspectos diversos da gestão pública, como por exemplo o transporte público, saneamento básico, coleta de lixo etc. (MONIÉ, 2003, p. 60).

Com a promulgação do Estatuto da Metrópole a situação da gestão dos territórios metropolitanos no Brasil passa a ter maior relevância. Até então muito se fazia confusão sobre os dispositivos genéricos constitucionais e faltava conteúdo mais técnico no sentido de deliberar a gestão intergovernamental com apoio de instrumentos regionais, como por exemplo o Plano de Desenvolvimento Urbano Integrado (PDUI) ${ }^{12}$.

Dentre duas diretrizes o parágrafo único do art. $2^{\circ}$ diz que caberá ao colegiado da Microrregião instituída decidir sobre a adoção do PDUI ou quaisquer outras matérias que tenham impacto na região. A LC $\mathrm{n}^{\circ} 105$ do ano de 2002 teria institucionalizado o Conselho Deliberativo da Microrregião dos Lagos (CDML), mas sem nenhum resultado prático efetivo voltado ao atendimento dos interesses comuns da Microrregião.

O Estatuto já traz uma imagem de Microrregião como uma facilidade de promoção de consórcios públicos entre os entes municipais envolvidos ${ }^{13}$. O que já é diferente quando se trata de

11 Para mais dados e informações acessar o site: https://cidades.ibge.gov.br/brasil/rj/cabo- frio/ pesquisa/23/25207?tipo=ranking.

12 art. $9^{\circ}$, inciso I da Lei ${ }^{\circ} 13.089$, de 12 de janeiro de 2015, que institui o Estatuto da Metrópole, altera a Lei $\mathrm{n}^{\circ}$ 10.257 , de 10 de julho de 2001, e dá outras providências. Disponível em:

http://www.planalto.gov.br/ccivil_03/_ato2015-2018/2015/lei/113089.htm. Acesso em: 15 mar. 2020. (BRASIL, 2015).

13 art. $14, \S 3^{\circ}$ da Lei $n^{\circ} 13.089$, de 12 de janeiro de 2015, que institui o Estatuto da Metrópole, altera a Lei ${ }^{\circ} 10.257$, de 10 de julho de 2001, e dá outras providências. Disponível em: http://www.planalto.gov.br/ccivil_03/_ato20152018/2015/lei/113089.htm. Acesso em: 19 mar. 2020. (BRASIL, 2015). 
RM ou aglomerados urbanos. Estes já contam com uma visão mais especializada pela legislação, pois sua formalização visa integrar uma organização para o planejamento e a execução de funções públicas de interesse comuns ${ }^{14}$, as microrregiões não foram aqui incluídas.

Trata-se de um ponto importante a ser debatido sobre o modo de visualizar o município de CF e a Região dos Lagos ao se querer tratar de governança interfederativa, o que ainda é muito debilitado nesta região. Legalmente, não se tem uma formalização do compartilhamento de responsabilidades e ações entres os entes da federação em termos de organização, planejamento e execução de FPICs (PINHEIRO, 2016, p. 104).

Talvez o maior desafio que os gestores públicos enfrentam atualmente, em nível de planejamento regional, seja o da governabilidade de regiões metropolitanas, aglomerados urbanos ou microrregiões. Isso se deve ao padrão ainda fragmentado que acaba sendo a praxe entre os municípios pertences a estas regiões de comum interesse. A ausência de uma formalização da governança federativa na Microrregião Lagos evidencia que mesmo os municípios dispostos em um contexto de compartilhamento de interesses ainda estejam contando com políticas públicas pontuais e fragmentadas. A situação contribui para o crescimento da lógica competitiva quando poderiam haver forças para o desenvolvimento regional equânime (CORDEIRO, 2016, p. 89).

Ao se considerar que a aglomeração urbana de CF pode lançar mão dos instrumentos dispostos no Estatuto da Cidade, de forma a racionalizar toda a gestão que é precária em toda a Microrregião Lagos, muitos problemas públicos comuns poderiam ser facilmente solucionados, como é o caso do transporte público intermunicipal que tem sido um dos gravames sociais da comunidade da Regiões dos Lagos. São diversos os fatores que fogem da realidade vivenciada pela sociedade bem como falta uma gestão mais equilibrada, capaz de implantar uma política mais condizente com a realidade da região (PINHEIRO, 2016, p. 105).

Há ainda especulações sobre a possibilidade dos aglomerados urbanos do norte do Estado do Rio de Janeiro estarem em um processo incipiente de metropolização. Isso porque suas taxas de crescimento, em relação ao crescimento urbano do Estado, têm chamado atenção. Entender se essa possível região metropolitana corresponderá a finalidade do Estatuto da Metrópole é interessante aqui considerar, pois não há dúvidas quanto a existência de interesses comuns, o que se pergunta é se será efetivo, visto que a formalização da Microrregião não rompeu com a fragmentarização das políticas, nem da falta de transparência e nem dos meios participativos dos diversos organismos sociais (TERRA; SOOUZA, 2017, p. 831).

É o caso do consórcio intermunicipal Lagos São João, que é composto pelos prefeitos da Microrregião dos Lagos. A ideia é de trazer uma gestão cooperativa entre os seus associados, entidades da sociedade civil e empresas voltada para o meio ambiente. Visando dar maior efetividade a tutela da rica fauna e flora da região, sua formalização se deu em 1999 com auxílio da Secretaria de Meio Ambiente e Desenvolvimento Sustentável do Rio de Janeiro. A iniciativa chamou tanta atenção que hoje conta com a participação de outros municípios de outras regiões do 14 art. $3^{\circ}$, caput da Lei ${ }^{\circ} 13.089$, de 12 de janeiro de 2015, que institui o Estatuto da Metrópole, altera a Lei ${ }^{\circ}$ 10.257, de 10 de julho de 2001, e dá outras providências. Disponível em:

http://www.planalto.gov.br/ccivil_03/_ato2015-2018/2015/lei/113089.htm. Acesso em: 19 mar. 2020. (BRASIL, 2015). 
Rio como Rio das Ostras, Rio Bonito, Silva Jardim e Cachoeira de Macacú ${ }^{15}$.

Dentre seus instrumentos o que mais teve repercussão foi a elaboração do Plano de Bacia. Trata-se da gestão interfederativa de recursos hídricos com propostas voltadas a identificação de ações, programas, projetos, obras e investimentos prioritários nas bacias hidrográficas e fontes hídricas da Região dos Lagos.

Além disso, mesmo ciente que há debilidade de uma gestão plenamente interfederativa na região, ainda assim a fragmentarização das ações tem se mostrado insuficientes. É o caso da criação do consórcio intermunicipal de Esporte da Região dos Lagos ${ }^{16}$ que sequer chegou a ter uma viabilidade prática. Outra política pública de interesse bastante comum não apenas na região, mas em toda baixada fluminense é a saúde. Sabe-se que a precariedade de infraestrutura tem obrigado as pessoas a procurarem serviços de saúde na RM do Rio de Janeiro. Criou-se em 2009 o consórcio intermunicipal de saúde da baixada litorânea (CISBALI $)^{17}$ que envolve a maioria dos municípios da região dos lagos e da região costa do sol.

Nas demais áreas, a Região dos Lagos tem alguns pontos relevantes a serem aqui também considerados. Nela o setor com maior participação no Valor Adicionado Bruto (VAB) ainda é o industrial, com cerca de 52,4\%, e se difere do restante do Estado do Rio de Janeiro, onde predomina os serviços comerciais $(51,2 \%)$, conforme os dados do observatório de gestão do SEBRAE-RJ que se propôs a montar um painel regional da Microrregião dos Lagos. Ainda assim, CF concentra $33 \%$ dos centros comerciais formais de toda região e mais da metade das empresas operantes (PAINEL..., 2016).

O município de CF apresentou o maior PIB (Produto Interno Bruto) dentre todos os demais municípios da Microrregião Lagos em 2015, com quase R\$ 17 bilhões. É o responsável por $54 \%$ de todo PIB da região.

Em contrapartida, verificou-se que a região carece de medidas e instrumentos que visem a eficiência de políticas públicas voltadas a áreas urbanas. Isso porque como dito antes suas ações tem sido ainda isoladas, deixando de lado uma possível gestão intergovernamental mais estruturada. O TCE chega a fazer algumas notas no ano de 2014, atestou que todos os municípios da Região Lagos apresentaram despesas acima das receitas arrecadadas. CF está no $1^{\circ}$ lugar do ranking com uma receita média declarada de $\mathrm{R} \$ 884$ milhões contra $\mathrm{R} \$ 931$ milhões de despesas, contando com uma autonomia financeira de apenas 32\% (PAINEL..., 2016, p. 11).

Considerando o motivo trabalho um fator determinante, o aglomerado urbano de CF abrange considerável fluxo pendular de deslocamento urbano entre os municípios da região e

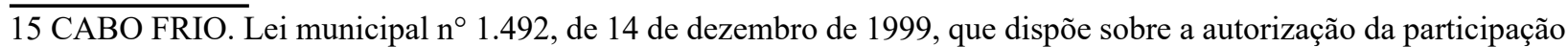
do município de Cabo Frio na constituição do Consórcio Intermunicipal para Gestão Ambiental das Bacias da Região dos Lagos. Disponível em: http://cabofrio.legislativomunicipal.com/arquivos/12454/LEI_1492_1999_0000001.pdf . Acesso em: 27 mar 2020. (CABO FRIO, 1999).

16 CABO FRIO. Lei municipal $n^{\circ} 2.208$, de 05 de agosto de 2009, que dispõe sobre a autoriza a participação do município de Cabo Frio na constituição do consórcio intermunicipal de esporte-região dos lagos, e dá outras providências. Disponível em: http://cabofrio.legislativomunicipal.com/arquivos/15758/LEI_2208_2009_0000001. pdf. Acesso em: 27 mar. 2020. (CABO FRIO, 2009).

17 Com ratificação pela lei municipal de Cabo Frio $\mathrm{n}^{\circ} 2.547$, de 20 de janeiro de 2014, que ratifica o protocolo de intenções firmado pelo município de Cabo Frio para constituição do consórcio intermunicipal de saúde da baixada litorânea - CISBALI, nos termos e condições que menciona. Disponível em: http://cabofrio.legislativomunicipal. com/arquivos/17411/LEI_2547_2014_0000001.pdf. Acesso em: 2 abr. 2020. (CABO FRIO, 2014). 
até mesmo à RM do Rio de Janeiro. O que se observa é que essa pendularidade é estrita, ou seja, por conta da proximidade física entre os municípios. Levando em consideração a distância entre os centros urbanos, de Cabo Frio até Armação de Búzios temos não mais de $20 \mathrm{~km}$, até Arraial do Cabo são $12 \mathrm{~km}$, até São Pedro da Aldeia são $12 \mathrm{~km}$, até Iguaba Grande são $26 \mathrm{~km}$ e até Araruama são 40 km (AZEVEDO; LOBO, 2015, p. 45-78). Será uma discussão a ser aprofundada no próximo tópico.

\section{DA POLÍTICA DE MOBILIDADE URBANA: TRANSPORTE PÚBLICO INTERMUNICIPAL NA MICRORREGIÃO DOS LAGOS}

\subsection{DA POLÍTICA DE TRANSPORTE COLETIVO INTERMUNICIPAL NA REGIÃo DOS LAGOS}

Não há dúvidas de que dentre as FPICs de todas as regiões metropolitanas no país a mobilidade urbana é reconhecida como sendo um dos seus eixos principais ${ }^{18}$. Mais ainda, a mobilidade urbana sempre foi demasiadamente importante na caracterização da Microrregião dos Lagos. Exponencial imprescindível já que, dentre as principais atividades econômicas ali desenvolvidas, estão o turismo, indústria e a locomoção de trabalhadores urbanos.

Todavia, o transporte urbano intermunicipal dentro da Microrregião dos Lagos sempre fora um grande desafio para a população. Um dos maiores conluios empresariais de transporte dominam até hoje a região. Duas são as empresas de ônibus, as únicas responsáveis pela execução da política pública de mobilidade urbana intermunicipal pública, mas também são as duas únicas que monopolizam toda a atividade.

A viação Salineira (também conhecida como Viação SMS - Salineira, Montes Brancos e São Pedro da Aldeia) e a auto viação 1001 são as duas empresas que oferecem o transporte público intermunicipal. Somente a Salineira é a que, além de ter linhas intermunicipais, também possui linhas municipais nas cidades de Cabo Frio, São Pedro da Aldeia e Araruama. Para fins de dar melhor recorte à discussão para aprofundar nas problemáticas existentes dentro da região dos Lagos, o presente estudo se concentrará na Viação Salineira.

Qual a problemática aqui debatida? A do abuso do aumento das tarifas de ônibus intermunicipais e qual sua relação com o plano de desenvolvimento integrado para a região no que tange aos transportes públicos intermunicipais. Tem-se o conhecimento de que esse aumento cada vez mais é reconhecido como abusivo pela população. Um círculo vicioso que não tem fim por uma série de fatores, dentre eles a perda na concorrência do transporte público pelo privado. Isso se agrava mais ainda quando se está diante de serviços públicos prestados sem a devida qualidade e eficiência que delas se espera.

18 O Estatuto da Metrópole tutelou um caso específico aonde se tem duas cidades gêmeas localizadas nas fronteiras com outros países. Nesse viés é dever da União garantir a mobilidade urbana, enquanto FPIC voltado ao desenvolvimento urbano. Vide: art. 16 da Lei $\mathrm{n}^{\circ}$ 13.089, de 12 de janeiro de 2015, que institui o Estatuto da Metrópole, altera a Lei $\mathrm{n}^{\circ}$ 10.257, de 10 de julho de 2001, e dá outras providências. Disponível em: http://www.planalto.gov.br/ccivil 03/ ato2015-2018/2015/lei/113089. htm. Acesso em: 15abr. 2020. BRASIL, 2015). 
Para melhor ilustrar o aumento das tarifas decorrem da correlação que existe entre o custeio dos insumos, o número de passageiros efetivamente pagantes e a concorrência. Como na Microrregião dos Lagos não há uma concorrência para a empresa Viação Salineira, então sobre a esta lidar com a concorrência do transporte privado. A ausência do elemento concorrência, no campo da econômica, automaticamente reflete um serviço de péssima qualidade, prestado de qualquer maneira.

Não obstante, o caráter desafiador está na consecução de uma política pública de longo prazo sem drásticas alterações para o transporte coletivo urbano, seja ele municipal ou intermunicipal. As novas dinâmicas que nascem da sociedade necessariamente terão reflexo nas tarifas de ônibus. Nesse sentido é que se pretende aqui discutir a possibilidade de gesticular essa demanda sob a ótica de uma governança interfederativa na Microrregião dos Lagos.

No Estado do Rio de Janeiro foi instituída uma autarquia estadual, vinculada à Secretaria de Estado de Transportes, que possuirá competências para fazer concessões, dar permissão, autorização, planejamento, coordenação, fiscalização, inspeção, vistoria e administração dos serviços intermunicipais de transporte de passageiros. A DETRO (Departamento de Transportes Rodoviários) cuida da fiscalização de aproximadamente 90 empresas de ônibus que operam em mais de 1.200 linhas $^{19}$.

O DETRO tem sido o órgão executor responsável pela fiscalização e implementação do transporte coletivo urbano intermunicipal também da Região Lagos. Fazendo uma comparação nestes últimos 10 anos em 2009 o valor da tarifa de ônibus intermunicipal que faz conexão com os municípios de Cabo Frio, Armação de Búzios, Arraial do Cabo, São Pedro da Aldeia, Iguaba Grande e Araruama era de R \$ 3,15 (três reais e quinze centavos) ${ }^{20}$. Em 2019 o mesmo itinerário acima descrito sofreu diversos reajustes tarifários, chegando à monta atual de $\mathrm{R} \$ 5,40$ (cinco reais e quarenta centavos $)^{21}$. Dentro destes últimos 10 anos o coeficiente de reajuste tarifário foi não menos que 0,7142 .

Depreende-se que os coeficientes tarifários das linhas e seções do sistema de transporte coletivo rodoviário intermunicipal acabam recebendo um tratamento diferenciado pela DETRO quando se trata de serviços prestados dentro da RM do Rio de Janeiro e dos serviços rodoviários não metropolitanos. De fato, essa distinção acaba corroborando para a vulneração da população de outras regiões fora da metropolitana, como é o caso da Região Lagos. Afinal, a Microrregião possui peculiaridades que a distinguem completamente das diretrizes perseguidas pela autarquia que generaliza as demandas metropolitanas para o resto dos municípios.

Essa falta de estudo técnico tem propiciado um retardamento da política urbana coletiva

19 RIO DE JANEIRO. Lei Estadual n ${ }^{\circ} 1.221$, de 6 de novembro de 1987, que dispõe sobre a criação do departamento de transportes do Estado do Rio de Janeiro - DETRO/RJ e da outras providências. Disponível em: https://gov-rj. jusbrasil.com.br/legislacao/90993/lei-1221-87. Acesso em: 15 abr. 2020. (RIO DE JANEIRO, 1987).

20 Portaria DETRO/PRES. N ${ }^{\circ}$ 915, de 12 de dezembro de 2008. Dispõe sobre a autorização de novas tarifas para o sistema de transporte rodoviário intermunicipal de passageiros no estado do Rio de Janeiro. Disponível em: http:// www.detro.rj.gov.br/uploads/portarias/Portaria\%20915-08\%20-\%20Reajuste\%20tarifário.pdf. Acesso em: 17abr. 2020. (RIO DE JANEIRO, 2008).

21 Portaria DETRO/PRES. N ${ }^{\circ} 1448$, de 6 de fevereiro de 2019. Dispõe sobre autorização de novas tarifas para o sistema de transporte rodoviário coletivo intermunicipal de passageiros no estado do Rio de Janeiro. Disponível em: http://www.detro.rj.gov.br/uploads/portarias/Portaria\%201448.pdf. Acesso em: 15/04/2020. (RIO DE JANEIRO, 2019b). 
intermunicipal. No dia 16 de novembro de 2015 aconteceu na escola municipal Professor Edilson Duarte, em Cabo Frio, audiência pública $n^{\circ}$ 01/15, promovido pela DETRO, com objetivo de colher um feedback populacional para construção dos futuros editais de licitação para concessão de serviços públicos de exploração de transporte rodoviário intermunicipal coletivo pelos próximos 20 anos.

Uma das teclas mais batidas nesta audiência foi se a empresa vencedora apresentaria planilha de valores de tarifas diferenciadas para as linhas que tenham menor quilometragem do que as demais ${ }^{22}$. Diferentemente da RM do Rio de Janeiro que contam com uma gama de empresas concorrentes, a Microrregião dos Lagos sempre esteve servida apenas dos serviços da viação Salineira. Seus itinerários obedecem às disposições intermunicipais da DETRO, ainda que a quilometragem entre os municípios seja inferior à da RM do Rio.

A título exemplificativo, o ônibus que faz integração entre os municípios de Cabo Frio e São Pedro da Aldeia tem tarifa de R \$ 5,40. A mesma tarifa é cobrada em outra linha que faz a integração entre Cabo Frio e Saquarema. A diferença em quilômetros partindo de cabo frio entre os municípios de São Pedro da Aldeia e Saquarema é de $51 \mathrm{~km}$. Em outras palavras, é dizer que existe uma disparidade entre os reais custos de insumos necessários (diesel, pneus, óleo, manutenção, etc.) em relação ao valor que é cobrado na tarifa. Os municípios mais próximos de Cabo Frio possuem uma distância de não mais que $12 \mathrm{~km}$, menos de 15 minutos de viagem. Todavia, a divisão limítrofe municipal estaria legitimando a Viação Salineira a tabelar uma tarifa desproporcional nos moldes metropolitanos.

Sendo a única empresa de transporte que ali domina a região a população não tem outra escolha, senão render-se aos constantes reajustes tarifários que destoam da realidade da região. O que fica evidente é que dentre a institucionalização da DETRO não se tem uma distribuição igualitária dos coeficientes tarifários, sem que se leve em conta os moldes metropolitanos do Rio de Janeiro. Questiona-se como solução uma possível institucionalização de um órgão próprio capaz de gerir uma política urbana coletiva intermunicipal que efetivamente atenda as necessidades da Região dos Lagos.

A ausência de concorrência e a precarização do serviço prestado acabam fomentando o desenvolvimento do mercado informal do transporte privado. A própria falta de fiscalização do DETRO é prova do crescimento informal da operação de vans e automóveis de passeio na região. A ineficiência fiscalizatória contribui para a oneração do serviço público de interesse comum, na medida em que a redução do número de passageiros resulta na perda do retorno aguardado pela empresa. É inegável que a necessidade de circular dentro da região é de suma importância para o desenvolvimento urbano e econômico, de modo que a sociedade acaba encontrando outras formas, embora informais, para servisse de uma política pública de natureza interfederativa comum.

Um dos grandes feitos que facilitou a vida dos cidadãos da RM do Rio de Janeiro foi a promulgação da Lei que institui o bilhete único nos serviços de transporte coletivo intermunicipal. O benefício de um valor único ainda é restrito a RM e não se aplica as demais regiões fluminenses ${ }^{23}$. 
A gestão dos interesses metropolitanos prevalece sobre os interesses das demais regiões, ao ponto de evidenciarmos aqui um certo desleixo político institucional.

Acredita-se que nessa medida, dada a tamanha relevância que a região dos lagos tem tomado, principalmente quando falamos na possibilidade de institucionalização de um aglomerado urbano, para solucionar estas questões que envolvem os interesses comuns dos municípios vizinhos seria interessante investir em uma gestão interfederativa própria. Não existe também por parte da DETRO um fomento que viabilize a competitividade dentro da prestação de serviços urbanos coletivos intermunicipais na microrregião dos Lagos, pois com ela a população terá serviços de maior qualidade sendo prestados. Outro agravante está na inefetividade das diretrizes políticas até então já constatados pela execução do DETRO quando consideramos que as concessões tem duração de longo prazo de 20 anos.

É imprescindível haver uma remodelagem do cenário político e interfederativo da Microrregião dos Lagos, para que de fato possa existir um plano de desenvolvimento urbano integrado capaz de atender as demandas comuns da Região dos Lagos. Algumas propostas serão aqui apresentadas com fins de buscar outras alternativas capazes de corroborar com a estimulação tanto da empresa para prestar serviços de qualidade por uma tarifa mais justa como também modernizar o serviço de transporte intermunicipal, de um modo mais condizente com a realidade local.

\subsection{Da POSSIBILIDAde DE DESENVOLVIMENTO DE UM PLANO DE DESENVOLVIMENTO URbano INTEGRADO PARA O TRANSPORTE INTERMUNICIPAL}

O Estatuto da Metrópole dispõe que será um dos instrumentos à disposição das RM e dos aglomerados urbanos a elaboração de um Plano de Desenvolvimento Urbano Integrado (PDUI) que, por sua vez, caracteriza uma gestão plena interfederativa com fins de estabelecer as diretrizes gerais de políticas públicas de comum interesse ${ }^{24}$. É inegável que a região dos lagos que ali se concentram verdadeiro aglomerado urbano ao redor de CF torna viável pensarmos em um processo constante de organização e planejamento, voltado a viabilização econômica e social de demandas econômicas e sociais comuns da região que estejam direta ou indiretamente ligadas a estruturação de uma regionalização política, como é o caso do transporte urbano coletivo intermunicipal.

O compartilhamento de responsabilidades e a pesquisa para obtenção de recursos tem se mostrado cada vez mais o melhor caminho para a Região dos Lagos pensar em uma alternativa de alterar positivamente o seu atual quadro de mobilidade urbana pública intermunicipal depreciada (CORDEIRO, 2016, p. 176). A desconstituição de um monopólio empresarial precisa ser não uma alternativa, mas uma decisão incisiva com fito de melhorar a própria qualidade da prestação de

único nos serviços de transporte coletivo intermunicipal de passageiros na região metropolitana do estado do Rio de Janeiro e dá outras providências. Disponível em: http://alerjln1.alerj.rj.gov.br/contlei. nsf/69d90307244602bb032567e800668618/76de911502259106832576a10060ff9f?OpenDocument. Acesso em: 15 abr. 2020. (RIO DE JANEIRO, 2009b).

24 . art. $2^{\circ}$, inciso VI da Lei $n^{\circ} 13.089$, de 12 de janeiro de 2015, que institui o Estatuto da Metrópole, altera a Lei $n^{\circ} 10.257$, de 10 de julho de 2001, e dá outras providências. Disponível em: http://www.planalto.gov.br/ccivil_03/_ato2015-2018/2015/lei/ 113089.htm. Acesso em: 29 abr. 2020. RIO DE JANEIRO, 2015). 
serviços pelas viações de ônibus. Isso fará com que os próprios municípios venham a homogeneizar suas legislações de modo que a suas peculiaridades regionais sobressairão as adequações legislativas e políticas que a DETRO faz do contexto metropolitano para todas as demais regiões fluminenses.

Isso fará com que a própria região passe a administrar seus próprios interesses. A precarização do serviço prestado pela Viação Salineira fomenta o mercado informal de transporte privado ofertados por automóveis de passeios. Não é difícil encontrar diversos grupos em redes sociais que foram criados com esse propósito. Uma gestão interfederativa própria da região será capaz de propiciar a própria sociedade uma participação democrática. A ausência de fiscalização, que é uma ação demasiadamente deficiente por parte da DETRO na Região Lagos, pode voltar a atender as expectativas da razoabilidade e eficiência.

A institucionalização de uma entidade autárquica própria demandaria antes a criação de um aglomerado urbano ou de uma RM de Cabo Frio. Todavia, não descartamos que um órgão gestor da execução das diretrizes dos planos de desenvolvimento urbano integrado seria um importante viés para melhorar a qualidade dos serviços de transporte público na região. Necessário seria a criação de um parlamento especial regional para que houvesse essa troca de experiências entre as câmaras municipais dos entes participantes. Da mesma forma, o gestor regional ficaria incumbido de planejar ações empreendedoras. A captação de recursos e a criação de um fundo é imprescindível para a efetividade das propostas do plano de desenvolvimento. Certo que o órgão executor deverá não apenas contar com agentes técnicos, mas obrigatoriamente abrir portas as demais entidades sociais organizadas.

Uma das colunas basilares do constante reajuste tarifário vem da ausência da participação social. A DETRO disponibiliza apenas a realização de uma única audiência pública promovida nas regiões fora da RM do Rio de Janeiro. Significa dizer que desde sua institucionalização há uma desproporcionalidade política institucional para com as demais regiões fora da RM. É o que se explica quando tais órgãos sequer viabilizam os contratos de concessão, como é o caso da concessão à Viação Salineira.

Sem esse controle regional os reajustes acabam sendo feitos sem levar em consideração as reais demandas regionais, mas acabam reajustando apenas em cima das necessidades apresentadas pelas empresas de transporte. A DETRO tem disponibilizado planilhas tarifárias das empresas para justificar os reajustes anuais, mas essa prestação de contas é recente somente começou a partir de 2018. É possível verificar que a discriminação leva em consideração dois tipos de critérios: 1) o que seriam despesas mínimas para a prestação de serviços pelas empresas dentro da região metropolitana; e 2) o que seriam despesas mínimas para prestação dos serviços pelas empresas fora da região metropolitana ${ }^{25}$. O segundo critério acaba sendo servido de parâmetros amplos e abstratos para que se adeque as demandas regionais fora da RM. Contudo, sabe-se que essa não é a melhor alternativa de equilibrar os interesses socias regionais e os interesses econômicos das viações de ônibus.

A solução possível pela institucionalização de um órgão interfederativo próprio da Região

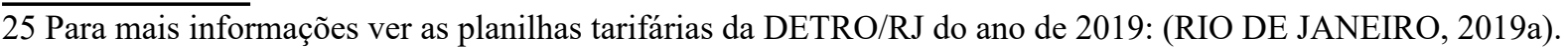


dos Lagos acaba sendo, por um outro viés, um desafogamento da centralização das competências da DETRO, que certamente seria mais eficiente se voltado apenas aos interesses da RM do Rio enquanto que fiscalizasse apenas as demais regiões a fora. A Política Nacional de Mobilidade Urbana $^{26}$ dispõe sobre outra alternativa acerca da precarização dos serviços de transporte urbano coletivo intermunicipal muito pouco explorado. Trata-se do financiamento por meio de recursos alternativos que visam o barateamento da tarifa e evitar o engessamento do setor público provenientes da União desde que preenchidas as diretrizes da PNMU.

Não se pode olvidar que uma das principais peculiaridades dos municípios que compõe a Região dos Lagos está na proximidade entre os municípios, ao ponto de que quilometragem deve ser preponderante na hora do tabelamento de preços que, inclusive, devem obrigatoriamente constarem nos editais de licitações. A viação Salineira utiliza-se do tabelamento único, isto é, a fixação de tarifas não mutáveis para uma mesma linha. A empresa leva em conta para o tabelamento apenas o critério da ultrapassagem dos limites intermunicipais.

Tem sido uma debilidade grande para a Região dos Lagos, pois que a ausência de fiscalização do tabelamento dos preços pelo critério da intermunicipialidade acaba extrapolando o binômio insumos x consumo, ou seja, não se tem, de fato, uma justiça social regional vigente.

Para além das soluções políticas faz-se necessário haver soluções econômicas e de fontes de financiamento que garantam o amplo acesso público aos serviços de transporte público intermunicipal. Chamamos atenção para a alternativa de revisões das políticas de estacionamento da cidade e/ou implementação de pedágios urbanos em vias para desestimular o transporte privado em detrimento da melhora da qualidade do transporte público (CARVALHO, 2016a, p. 24-27).

Neste caso pode os municípios instituírem um fundo específico para depositar os recursos advindos da exploração dos estacionamentos públicos. Trata-se de meio alternativo de verba que pode auxiliar muito na subsidiação das tarifas de ônibus. Tanto o estacionamento público quanto a implantação do pedágio são espécie de cobrança pelo uso do espaço público urbano. Certamente será um modelo de financiamento da executoriedade e manutenção do sistema de transporte público coletivo intermunicipal dentro da região, isso levando em consideração a necessidade de mobilidade constante entre os municípios vizinhos (característica importante dentro da Região dos Lagos) (CARVALHO, 2016b, p. 19-21).

Em outro viés, a política de gestão de estacionamento públicos e de pedágios serve como verdadeiro instrumento de desestímulo para o crescimento progressivo do uso de automóveis particulares, o que implica consequentemente em uma busca pelo melhoramento do serviço público de transporte. Como por exemplo: a implementação de tarifas em pontos estratégicos como faculdades, praias, shoppings e centros comerciais, podem favorecer a utilização do transporte público (GOMIDE; MORATO, 2011, p. 48-50). A implementação de pedágios não deixa de ser medida que diminui a escolha dos usuários pelo transporte privado. Assim, buscarão outros meios, como o transporte público intermunicipal.

26 Art. 16 da Lei ${ }^{\circ}$ 12.587, de 3 de janeiro de 2012, que institui as diretrizes da Política nacional de Mobilidade Urbana e da outras providências. Disponível em: http://www.planalto.gov.br/ccivil_03/_ato2011-

2014/2012/lei/112587.htm. Acesso em: 3 maio 2020 (BRASIL, 2012). 
Há outro instrumento econômico perfeitamente adaptável para dentro de um modelo de governança interfederativa tem ligação com condução de subsídios provenientes da contribuição de intervenção no domínio econômico (CIDE - COMBUSTÍVEL) para o transporte público coletivo intermunicipal na região lagos. Há discussão acerca da chamada CIDE Municipal - PEC 159/2007. Por anos no país as políticas incentivaram a aquisição e o uso de veículos de passeio. Em contraponto, deixou-se de lado medida que obrigassem os empresários a trazer melhorias e uma constante eficiência e modernização dos serviços de transportes públicos, assim como um encarecimento das suas tarifas. Tamanho desequilíbrio econômico incorre no fomento do transporte ilegal, um dos núcleos da queda do número de usuários de ônibus.

A CIDE municipal se trata de uma contribuição direcionada para os usuários de transporte individual motorizado (automóveis e motocicletas) incidindo sobre a gasolina, o etanol e o gás natural veicular (GNV), este último bastante comum na Região dos Lagos. A criação de um fundo regional facilitaria o custeio de parte das operações de transporte público coletivo intermunicipal, contribuindo para uma redução significativa das tarifas (FREITAS, 2013, p. 379-392). Os benefícios são diversos, como: a redução de congestionamentos intermunicipais, melhorias na prestação de serviços de transporte, redução das tarifas cobradas, alívio dos orçamentos municipais e valorização de uma justiça social sobre o direito de mobilidade e circulação.

E, finalmente, uma vantagem considerável da Região dos Lagos está na participação que tem todos os municípios sobre os royalties de petróleo. Dados fornecidos pela Agência Nacional do Petróleo relevam que somente no ano de $2018^{27}$ a Região dos Lagos teve um acúmulo de R \$ 456 milhões. Os municípios da região possuem um exponencial considerável dentro da participação dos royalties de petróleo. Caso interessante de abordarmos nesta discussão é a o do município de Maricá/RJ que é o único município brasileiro que conta com mais de 100 mil habitantes e que oferece ônibus com tarifa zero. Apesar de se tratar de ônibus municipal, o modelo pode ser aplicado sob a ótica regional, pois financia as tarifas de ônibus com a fundação da Empresa Pública de Transportes (EPT) que instituiu o passe livre para todos. Foi possível graças parte dos recursos recebidos da distribuição dos royalties ${ }^{28}$.

\section{CONCLUSÃO}

É inegável que a Região dos Lagos, levando em consideração as potencialidades políticas, econômicas e sociais de Cabo Frio, exprimem uma relevante pertinência na ideia de institucionalização de um aglomerado urbano. Até então viu-se que a dinamização regional da Microrregião dos Lagos não trouxe de fato benefícios condizentes com a efetivação das FPICs.

Nesse âmago, se torna interessante a retomada de dados que esclarecessem os exponenciais regionais presentes sob a ótica do Estatuto da Metrópole e do viés cooperativo da Constituição Federal de 1988. Dado maior grau de importância e autonomia aos entes municipais, abre-se novas 27 Para mais informações, ver: Agência Nacional de Petróleo (2015).

28 Para mais informações, ver: Agenda Ambiental na Administração Pública (2019). 
portas através da governança interfederativa com fito de trazer um desenvolvimento para além do âmbito local, porém sem retirar o destaque ou a autonomia dos entes municipais.

Destaca-se o nascimento de uma nova figura: o gestor municipal. A partir deste recente cenário político institucional os agentes municipais necessariamente devem se qualificar como verdadeiros empreendedores e procurar meios alternativos de captação de recursos, utilizando os pontos fortes de cada localidade como o turismo, indústria, agricultura, etc.

Dentro da Região dos Lagos o transporte público coletivo intermunicipal é mais que uma demanda comum, é um fator preponderante e importante para garantia do desenvolvimento regional. Torna-se discutível a oferta do serviço de forma esparsa e incondizente com as reais necessidades sociais e econômicas da região. O órgão responsável DETRO vem faltando com a fiscalização e a execução necessária que garantem a prestação de um serviço de transporte intermunicipal de melhor qualidade.

Pensar em meios alternativos que privilegiem uma gestão mais interfederativa e cooperacional é um meio eficaz sob a ótica constitucional de assegurar a concretização das propostas de demandas de interesse comum. A presente discussão tratou de elucidar a importância regional da Microrregião dos Lagos e a sua relevância, não apenas para dentro do âmbito nacional, mas também para aquilo que está fora da RM do Rio de Janeiro, principalmente sob a ótica da política de transporte público coletivo intermunicipal.

\section{REFERÊNCIAS}

AGÊNCIA NACIONAL DO PETRÓLEO, GÁS NATURAL E BIOCOMBUSTÍVEIS.

Royalties. Brasília: ANP, 2020. Disponível em: http://www.anp.gov.br/royalties-e-outrasparticipacoes/royalties. Acesso em: 10 jun. 2019.

AGENDA AMBIENTAL NA ADMINISTRAÇÃO PÚBLICA - A3P. TRANSPORTE público gratuito em Maricá. Brasília: A3P, [2019?]. Disponível em: https://a3p.eco.br/produto/transportepublico-gratuito-em-marica/. Acesso em: 27 jun. 2019.

AZEVEDO, Sergio; LOBO, Yolanda. O processo de fusão e o novo Estado do Rio de janeiro: a questão institucional. In: RIBEIRO, Luis Cesar de Queiroz (org.). Rio de Janeiro: transformações na ordem urbana. Rio de Janeiro: Letra Capital; Observatório das Metrópoles, 2015. p. 43-78. (Coleção Metrópoles: Território, coesão social e governança democrática).

BRASIL. [Constituição (1988)]. Constituição da República Federativa do Brasil de 1988.

Brasília: Presidência da República, 1988. Disponível em: http://www.planalto.gov.br/ccivil_03/ constituicao/constituicao.htm. Acesso em: 12 maio 2019.

BRASIL. Lei $\mathbf{n}^{\mathbf{0}}$ 12.587, de 3 de janeiro de 2012. Institui as diretrizes da Política Nacional de Mobilidade Urbana; revoga dispositivos dos Decretos-Leis n's 3.326, de 3 de junho de 1941, e 5.405, de 13 de abril de 1943, da Consolidação das Leis do Trabalho (CLT), aprovada pelo Decreto-Lei $\mathrm{n}^{\circ} 5.452$, de $1^{\circ}$ de maio de 1943, e das Leis $n^{\circ}$ s 5.917, de 10 de setembro de 1973, e 
6.261, de 14 de novembro de 1975; e dá outras providências. Brasília: Presidência da República, 2012. Disponível em: http://www.planalto.gov.br/ccivil_03/_ato2011-2014/2012/lei/112587.htm. Acesso em: 13 maio 2019.

BRASIL. Lei $\mathbf{n}^{\mathbf{0}}$ 13.089, de 12 de janeiro de 2015. Institui o Estatuto da Metrópole, altera a Lei $\mathrm{n}^{\circ} 10.257$, de 10 de julho de 2001, e dá outras providências. Brasília: Presidência da República, 2015. Disponível em: http://www.planalto.gov.br/ccivil_03/_ato2015-2018/2015/lei/113089.htm. Acesso em: 12 maio 2019.

CABO FRIO. Lei municipal $\mathbf{n}^{\circ}$ 1.492, de 14 de dezembro de 1999. Dispõe sobre a autorização da participação do município de Cabo Frio na constituição do Consórcio Intermunicipal para Gestão Ambiental das Bacias da Região dos Lagos. Cabo Frio: 1999. Disponível em: http:// cabofrio.legislativomunicipal.com/arquivos/12454/LEI_1492_1999_0000001.pdf. Acesso em: 27 mar. 2020.

CABO FRIO. Lei municipal $\mathbf{n}^{\circ} \mathbf{2 . 2 0 8}$, de 05 de agosto de 2009. Autoriza a participação do município de Cabo Frio na constituição do consórcio intermunicipal de esporte-região dos lagos, e dá outras providências. Cabo Frio: 2009. Disponível em: http://cabofrio.legislativomunicipal. com/arquivos/15758/LEI_2208_2009_0000001.pdf. Acesso em: 15 mar. 2020.

CABO FRIO. Lei municipal $\mathbf{n}^{\circ} \mathbf{2 . 5 4 7}$, de 20 de janeiro de 2014. Ratifica o protocolo de intenções firmado pelo município de Cabo Frio para constituição do consórcio intermunicipal de saúde da baixada litorânea - CISBALI, nos termos e condições que menciona. Disponível em: http://cabofrio.legislativomunicipal.com/arquivos/17411/LEI_2547_2014_0000001.pdf. Acesso em: 2 abr. 2020.

CARVALHO, Carlos Henrique Ribeiro de. Aspectos regulatórios e conceituais das políticas tarifárias dos sistemas de transporte público urbano no Brasil. Rio de Janeiro: IPEA, 2016a.

CARVALHO, Carlos Henrique Ribeiro de. Desafios da mobilidade urbana no Brasil. Rio de Janeiro: IPEA, 2016b.

CORDEIRO, Glauber de Lucena. Regiões metropolitanas: o papel dos parlamentos metropolitanos na governança interfederativa do Estatuto das metrópoles (lei $\left.n^{\circ} 13.089 / 15\right)$. Rio de Janeiro Lumen Juris, 2016.

FREITAS, André Luís Policani. Assessing the quality of intercity road transportation of passengers: an exploratory study in Brazil. Transportation Research Part A- Policy and Practice, New York, v. 49, p. 379-392, mar. 2013.

FUNDAÇÃO GETÚlIO VARGAS. Plano Amaral Peixoto de urbanização das cidades fluminenses etapa inicial. 2009. Disponível em: http://www.fgv.br/cpdoc/acervo/arquivopessoal/AVAP/audiovisual/plano-amaral-peixoto-de-urbanizacao-das-cidades-fluminensesetapainicial. Acesso em: 11 jun. 2019.

GOMIDE, Alexandre de Ávila; MORATO, Renato. Instrumentos de desestímulo ao uso do transporte individual motorizado: lições e recomendações. São Paulo: Instituto de Energia e 
Meio Ambiente, 2011.

INSTITUTO BRASILEIRO DE GEOGRAFIA E ESTATÍSTICA. Arranjos populacionais e concentrações urbanas do Brasil. Rio de Janeiro: IBGE, 2015.

INSTITUTO BRASILEIRO DE GEOGRAFIA E ESTATÍSTICA. Cabo Frio: censo-sinopse. 2010. Disponível em: https:/cidades.ibge.gov.br/brasil/rj/cabo-frio/ pesquisa/23/25207?tipo=ranking. Acesso em: 21 jun. 2019.

MONIÉ, Frédéric. Petróleo, industrialização e organização do espaço regional. In: PIQUET, Rosélia (org.). Petróleo, royalties e região. Rio de Janeiro: Garamond, 2003. p. 257-285.

MOREIRA NETO, Diogo de Figueiredo. Curso de direito administrativo. 16. ed. São Paulo: Forense, 2014.

PAINEL regional: região dos Lagos. Rio de Janeiro: Sebrae, 2016. Disponível em: https://www. sebrae.com.br/Sebrae/Portal\%20Sebrae/UFs/RJ/Anexos/SebraePainel_RegiaoLagos.pdf. Acesso em:13 jun. 2019.

PINHEIRO, Olavo Pereira. Do processo de reestruturação socioespacial no município de Cabo Frio dos anos 1990-2010: o polo de uma nova aglomeração urbana? 2016. 117 f. Dissertação (Mestrado em Planejamento e Gestão de Cidades) - Universidade Candido Mendes UCAM, Campos dos Goytacazes, 2016.

RIO DE JANEIRO (Estado). Departamento de Transportes Rodoviários. Planilha de cálculo de reajuste tarifário. Rio de Janeiro: DETRO, 2019a. Disponível em: http://www.detro.rj.gov.br/ uploads/arquivos/planilha2019.pdf. Acesso em: 26 jun. 2019.

RIO DE JANEIRO (Município). Lei Complementar n. 105, de 04 de julho de 2002. Altera a lei complementar $n^{\circ} .87$, de 16 de dezembro de 1997 , com a nova redação dada pela lei complementar $n^{\circ} .97$, de 02 de outubro de 2001, e a lei complementar $n^{\circ} .89$, de 17 de julho de 1998, e dá outras providências, na forma que menciona. Rio de Janeiro: Gabinete do Prefeito, 2002. Disponível em: https://gov-rj.jusbrasil.com.br/legislacao/87467/lei-complementar-105-02. Acesso em: 12 abr. 2019.

RIO DE JANEIRO (Município). Lei Complementar n 133, de 15 de dezembro de 2009. Institui a operação urbana consorciada parque natural municipal da barra da tijuca, estabelece diretrizes urbanísticas para a área de abrangência delimitada na operação, permite a transferência de potencial construtivo, institui conselho consultivo e dá outras providências. Rio de Janeiro: Gabinete do Prefeito, 2009a. Disponível em: https://leismunicipais.com.br/a/rj/r/rio-de-janeiro/ lei-complementar/2013/13/133/lei-complementar-n-133-2013-institui-a-operacao-urbanaconsorciada-parque-natural-municipal-da-barra-da-tijuca-estabelece-diretrizes-urbanisticas-paraa-area-de-abrangencia-delimitada-na-operacao-permite-a-transferencia-de-potencial-construtivoinstitui-conselho-consultivo-e-da-outras-providencias. Acesso em: 12 maio 2019.

RIO DE JANEIRO (Município). Lei n ${ }^{\circ} .221$, de 6 de novembro de 1987. Cria o departamento de transportes rodoviários do Estado do Rio de Janeiro - DETRO/RJ e dá outras providências. 
Rio de Janeiro: Gabinete do Prefeito, 1987. Disponível em: https:/gov-rj.jusbrasil.com.br/ legislacao/90993/lei-1221-87. Acesso em: 14 abr. 2019.

RIO DE JANEIRO (Município). Lei n 5.628, de 29 de dezembro de 2009. Institui o bilhete único nos serviços de transporte coletivo intermunicipal de passageiros na região metropolitana do Estado do Rio de Janeiro e dá outras providências. Rio de Janeiro: Gabinete do Prefeito, 2009b. Disponível em: https://gov-rj.jusbrasil.com.br/legislacao/820940/lei-5628-09. Acesso em: 13 maio 2019.

RIO DE JANEIRO (Estado). Secretaria de Estado de Transportes. Atas das sessões públicas. Diário Oficial do Estado, Rio de Janeiro, ano 41, n. 214, p. 29-30, 2015. Disponível em: http:// www.detro.rj.gov.br/uploads/audiencias/Ata_da_Audiencia_Macae_Cabo_Frio_e_Teresopolis_ CCF27112015.pdf. Acesso em: 25 jun. 2019.

RIO DE JANEIRO (Estado). Secretaria de Estado de Transportes. Portaria DETRO/PRES. N. ${ }^{\circ}$ 1448 de 06 de fevereiro de 2019. Rio de Janeiro: DETRO, 2019b. Disponível em: http://www. detro.rj.gov.br/uploads/portarias/portaria1448.pdf. Acesso em: 19 jun. 2019.

RIO DE JANEIRO (Estado. Secretaria de Estado de Transporte. Portaria n 915, de 12 de dezembro de 2008. Autoriza novas tarifas para o sistema de transporte rodoviário intermunicipal de passageiros no estado do Rio de Janeiro. Rio de Janeiro: DETRO, 2008. Disponível em: http://www.detro.rj.gov.br/uploads/portarias/Portaria\%20915-08\%20-\%20Reajuste\%20tarifário. pdf. Acesso em: 17 mar. 2020.

TERRA, Denise Cunha Tavares; SOUZA, Joseane de. Rio de Janeiro: Rumo a uma nova região metropolitana? Cadernos Metropole, São Paulo, v. 19, n. 40, p. 801-826, set./dez. 2017.

Como citar: ANDRADE, Eric Santos; MOURA, Emerson Affonso da Costa. Cabo Frio e as potencialidades da Região Lagos: do plano de desenvolvimento integrado para o transporte público coletivo intermunicipal. Revista do Direito Público, Londrina, v. 16, n. 3, p. 168-191, dez. 2021. DOI: $10.5433 / 24157-108104-1.2021 v 16 n 3 p .168$. ISSN: 1980-511X

Recebido em: 26/06/2020

Aprovado em: 23/02/2021 